\title{
The Opportunity Cost of Forest Land Losses to Agricultural Uses: An Alberta Case Study
}

\author{
by \\ William E. Phillips', Glen W. Armstrong' ${ }^{1}$, James A. Beck, Jr. ${ }^{1}$ and Kamal Banskota ${ }^{1}$
}

\begin{abstract}
A methodology for determining the opportunity cost of removing land from timber production is presented. The value of forested land in a jurisdiction that requires some form of sustained timber yield is based on the value contribution of that land to annual allowable cut. This methodology is used in a case study in the Peace River region of Alberta to determine the opportunity cost of removing an area of the region from timber production for potential expansion of the agricultural land base.
\end{abstract}

\section{Résumé}

Une méthodologie pour déterminerr le coût d'opportunité relié au retrait d'une propriété du domaine forestier est présentée. La valeur des terres forestières dans une circonscription qui exige une forme quelconque de rendement soutenu de la matière ligneuse est estimée à partir de la valeur de la contribution de ces terres à la coupe annuelle admise. Cette méthodologie a été utilisée lors d'une étude effectuée dans la région de Peace River en Alberta, afin de déterminer le coût d'opportunité du retrait d'une partie de la région du domaine forestier lors de l'expansion probable du territoire agricole.

\section{Introduction}

In the last decade, competition between agriculture and forestry for the use of Alberta's land resource has become increasingly apparent. The Environment Council of Alberta recently held a series of public hearings on the subject of maintaining and expanding the agricultural land base (1985). Alberta Agriculture prepared a report entitled "Potential for Agricultural Expansion Relative to Forestry in Northern Alberta" (K. MacDonald 1983). Alberta Energy and Natural Resources prepared a report with the focus on forestry land values in northern Alberta (Bigsby 1983). The effort expended by these government agencies illustrates the political importance of land use decisions in Alberta today.

A number of factors should be considered when making land use decisions. Employment, income distribution, financial impacts, regional disparity, and economic efficiency are all important criteria for assessing potential land use changes. This paper focusses on the economic efficiency criterion for evaluating potential land use changes from forestry to agriculture and applies the methodology in a case study in the Peace River region of Alberta. The exclusion of the other criteria is not a comment on their value for informing decision makers: consideration of these is not within the scope of this paper.

No attempt will be made in this study to compare the relative values of forestry and agriculture in the study area. The objective here is to evaluate the timber producing

iFaculty of Agriculture and Forestry, University of Alberta.

opportunities that would be foregone as a result of a land use change. If the value of the proposed agricultural expansion is greater than the value of the timber producing opportunities foregone, the proposed agricultural expansion is a more efficient use of the land than forestry. Otherwise it is not.

\section{Conceptual Framework}

Each land use alternative for a given parcel of land can conceivably generate a flow of economic rent over time. Economic rent is a measure of land productivity based on the value of final products less the costs associated with production, processing, distribution, and retailing. It is a residual value attributable to the land resource. The allocation of a tract of land to the land use alternative with the highest rent earning capacity maximizes economic efficiency: the present value of net benefits to society as a whole. The rent maximizing use of the land is its highest and best use.

The maximum annual timber harvest rates in Alberta are constrained by the province's sustained yield policy. Under sustained yield constraints, the value of a tract of land and the trees currently on it for timber production can be thought of as the value of their contribution to the annual allowable cut (AAC) of a forest management unit. This contribution can be calculated by estimating the allowable cut for a sustained yield forest management unit with and without the tract of land of interest, subtracting the two AACs, and determining the value of the lost timber production. This value represents the opportunity cost of removing the land from timber production and should be charged against the displacing land use. To achieve the benefits resulting from the land use change, the opportunities to gain benefits from timber production are 
foregone. The real benefit of land use change is net of the lost timber production opportunities.

\section{Opportunity Cost Model}

In our model, the opportunity cost of agricultural expansion into a forest management unit is the difference between the discounted values of the rent flow from potential timber production with no agricultural expansion and with agricultural expansion. For the sake of simplicity, we assume that only lumber and pulp chips will be manufactured from the harvested timber and that only coniferous timber has any value. Recent developments in the utilization of deciduous timber in Alberta indicate that deciduous timber does have a value. We did not include any analysis of the deciduous resource in this study but there is nothing in the model that would preclude its consideration.

All costs and revenues in our model are expressed in constant 1984 dollars. The discount rate is expressed in real terms as well, and is assumed to be constant over time. The net present value of each alternative is determined as follows:

$$
N P V=\sum_{t=1}^{\infty}\left[R_{t} /(1+i)^{t}\right]
$$

$i$ is the discount rate;

$t$ is the number of years from the present; and

$R_{t}$ is the economic rent earned in a given year.

The economic rent earned in any given year $\left(R_{t}\right)$ is the annual revenue earned from selling manufactured products (lumber and chips) less the annual costs of harvesting and milling. Annual milling costs include annual operating costs (including labour, energy, and supplies) and depreciation costs (including those for machinery, equipment, and buildings). Annual harvesting costs include annual operating and depreciation costs for a number of activities (roading, felling, skidding, decking, loading, hauling, and reforestation). Costs from government required reforestation are deducted from concurrent rent flows. Even though the returns from these investments are not realized until the future stands are harvested.

It is conceivable that merchantable timber could be salvaged from the agricultural expansion area during the clearing process. This potential salvage value should be subtracted from the opportunity cost estimate.

The opportunity cost model is

$$
O C=\left(N P V_{0}-N P V_{1}\right)-S R_{1}
$$

where: NPV is the net present value of the land base for timber production assuming no land use change; $\mathrm{NPV}_{1}$ is the net present value of the land base for timber production assuming the land use change occurs; and

$\mathrm{SR}_{1}$ is the value of any timber salvaged during the land clearing process.

In our formulation, the value of the salvaged timber $\left(\mathrm{SR}_{1}\right)$ is not discounted as it is assumed to be taken immediately. Other assumptions about the timing of the salvage could be made and would affect the results.

\section{Study Area}

The Peace River region of northern Alberta contains a large proportion of the potential area for agricultural expansion in the province. Much of this area is also very valuable for timber production: it is not surprising that many land use conflicts occur in this region. The current study considers the same region as the Alberta Agriculture study on the potential for agricultural development (K. MacDonald 1983) which focussed on Forest Management Units (FMUs) P4 and P5 of the Peace River Forest. These FMUs are located east of the Peace River, north of the eighty-sixth township line, and south of the ninety-seventh township line.

The total area of the two FMUs is 752240 ha of which 194986 ha are productive coniferous forest land. ${ }^{2}$ The potential agricultural expansion area occupies 168060 ha of the western portion of these FMUs; 95650 ha are considered arable for agricultural purposes (K. MacDonald 1983). If all of the potential expansion area were converted to agriculture, the area of productive coniferous forest land would be reduced by 31532 ha to $84 \%$ of the current timber land base.

Figure 1 illustrates the results of the forest land base determination for FMUs P4 and P5. Ninety-eight thousand ha of the gross land base are not managed by the Alberta Forest Service or are not in a forest quota area. Another 254800 ha are non-forested: this category includes muskeg, scrub lands, and other areas with little or no tree cover. Productive coniferous forest land occupies 195000 ha. Never merchantable coniferous forest land occupies 71000 ha. The total area under deciduous cover is 197400 ha.

Figure 2 shows the same information for the area of the two FMUs within the proposed agricultural expansion area. A far greater proportion of the area within the expansion area is under deciduous cover.

\section{Harvest Volume Estimates}

The basic AFS policy guiding the determination of an AAC for a Forest Management Unit is that the AAC should be set so that the volume harvested from the FMU over a selected conversion period is maximized subject to non-declining yield harvest level constraints. The harvest scheduling model Timber RAM (Navon 1971) is commonly used in western Canada to estimate allowable cuts under this type of policy and was used for this study.

The flow policy chosen for this analysis was to maximize the volume harvested in the first decade, allowing no decrease in the scheduled harvest volume over the next 11 decades, and no increase in scheduled volume from decade to decade greater than $10 \%$. In addition to this constraint, the average harvest of decades 13 through 32 was constrained to be at least as large as the long-range sustained yield average (LRSYA). LRSYA is a measure of the long-term productivity for a fully regulated forest management unit.

It was assumed that all harvested land would be regenerated so that future yields per hectare would be the same as current yields. A regeneration lag was incorporated into the yield curves for regenerated timber to allow for the ten years that the AFS permits to elapse before satisfactory regeneration is achieved.

Figure 3 shows the estimated AACs for FMU P4 both with and without agricultural expansion over the length of the

\footnotetext{
2The productive coniferous land base for these FMUs was estimated using merchantability criteria provided by the Alberta Forest Service. All stands that have (or will have at rotation age) at least $47.5 \mathrm{~m}^{3} /$ ha of coniferous timber measured to a $15 \mathrm{~cm}$ diameter stump and a $10 \mathrm{~cm}$ diameter top are considered part of the productive coniferous land base.
} 


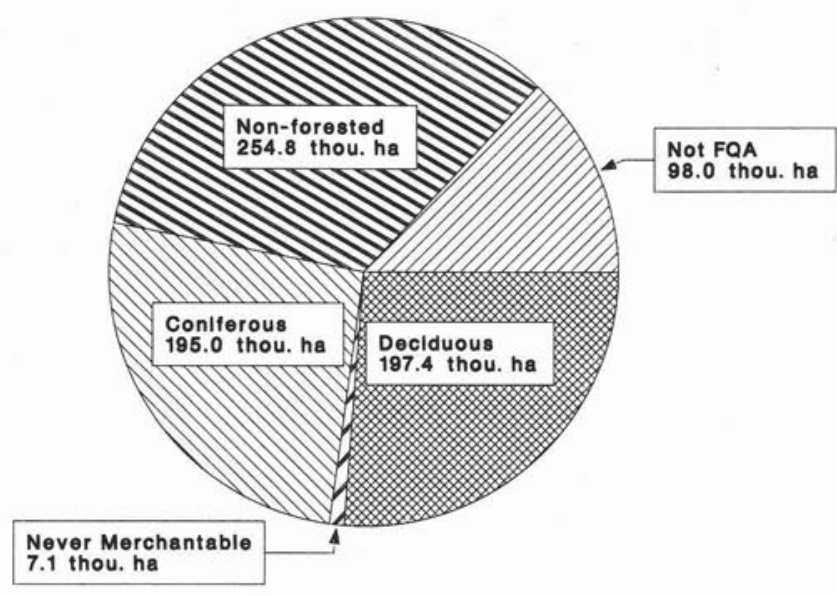

Figure 1. Results of forest land base determination for the entire area of FMUs P4 and P5.

planning horizon. Figure 4 presents the same information for FMU P5. Figure 5 shows the AAC that would be lost as a result of the agricultural expansion for each of the FMUs and the total lost AAC. The withdrawal of 31532 ha of productive coniferous land resulted in a reduction in LRSYA of $72900 \mathrm{~m}^{3} /$ year.

\section{Revenue Estimates}

A range of mill net selling prices for lumber (f.o.b. the mill) was selected for use in the opportunity cost model. The range of prices was selected in order to account for the fluctuations that occur in the price of lumber and to indicate the degree of sensitivity of the rent levels to different price levels. Based on data provided by the Alberta Forest Service, real lumber price levels of $\$ 40.00, \$ 50.00$, and $\$ 60.00 / \mathrm{m}^{3}$ of roundwood harvested were selected.

In addition to lumber prices, wood chip prices are required for the revenue model. Although chip prices also fluctuate, only one level was chosen for this study because wood chips contribute only about $10 \%$ to gross revenue. The price level chosen is $\$ 30.00 /$ bone dry unit (BDU) f.o.b. the mill. ${ }^{3}$

The application of a chip recovery factor (CRF) allows the expression of total mill revenue in terms of dollars per cubic metre of logs harvested. The $\mathrm{CRF}^{4}$ was set at $0.170 \mathrm{BDU}$ chips per $\mathrm{m}^{3}$ of roundwood harvested. This CRF assumes that chips are a byproduct of a sawmilling operation.

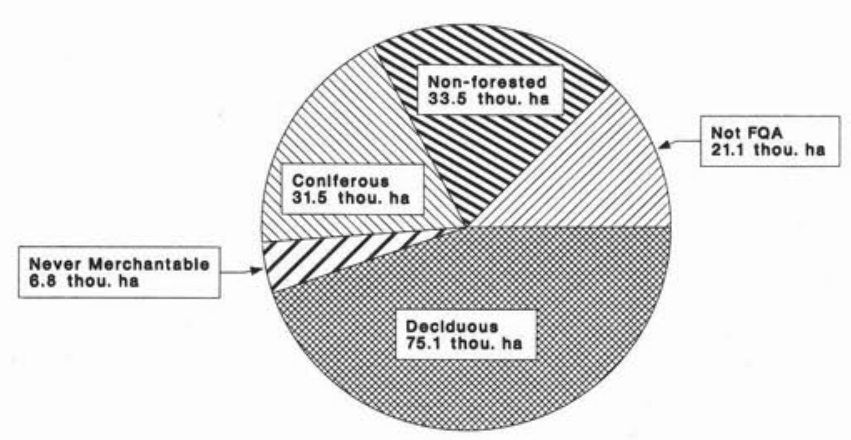

Figure 2. Results of forest land base determination for the area of FMUs P4 and P5 within the agricultural expansion area.

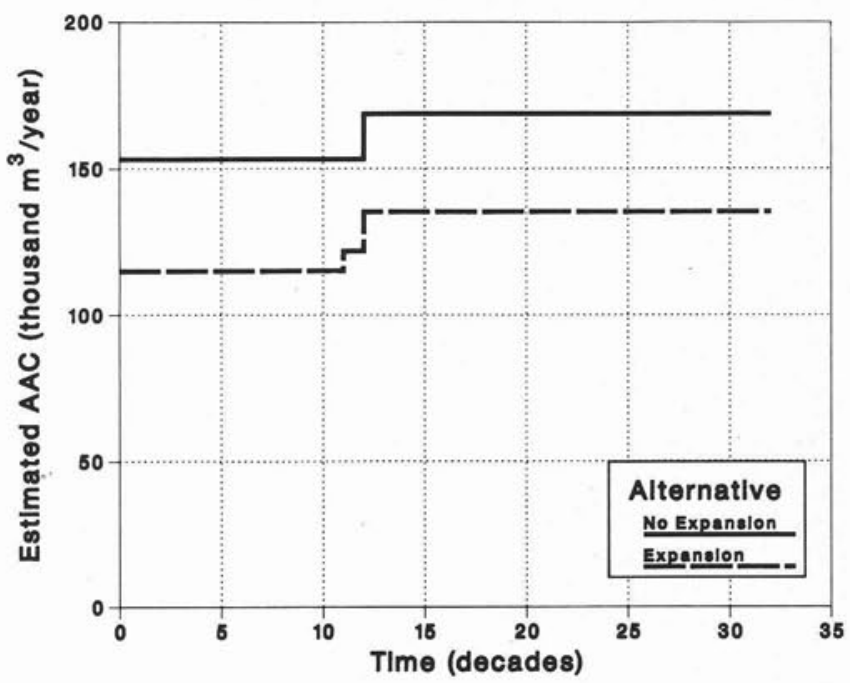

Figure 3. Estimated annual allowable cut ( $\mathrm{m}^{3} /$ year) for FMU P4 under the no agricultural expansion and agricultural expansion alternatives

Total revenue per cubic metre of logs harvested is calculated for the three lumber price levels as follows:

$$
\begin{aligned}
& \text { High: } \$ 60.00 / \mathrm{m}^{3}+[\$ 30.00 / \mathrm{BDU} \times 0.170]=\$ 65.10 / \mathrm{m}^{3} \\
& \text { Med.: } \$ 50.00 / \mathrm{m}^{3}+[\$ 30.00 / \mathrm{BDU} \times 0.170]=\$ 55.10 / \mathrm{m}^{3} \\
& \text { Low: } \$ 40.00 / \mathrm{m}^{3}+[\$ 30.00 / \mathrm{BDU} \times 0.170]=\$ 45.10 / \mathrm{m}^{3}
\end{aligned}
$$

Total annual mill revenue can be determined for the estimated AACs by multiplying the gross revenue per cubic metre of logs by the scheduled annual harvest volumes.

\section{Cost Estimates}

The average total costs of lumber and chip production in Alberta vary considerably. Recent estimates range from $\$ 36.00 / \mathrm{m}^{3}$ to $\$ 58.00 / \mathrm{m}^{3}$ of roundwood harvested (K. MacDonald 1983, Bigsby 1983). The range of costs used in this study are based on the results of these previous studies. We selected a low cost level of $\$ 39.50 / \mathrm{m}^{3}$ of roundwood harvested, a medium cost level of $\$ 46.50 / \mathrm{m}^{3}$, and a high cost level of $\$ 53.50 / \mathrm{m}^{3}$. These costs are all mill site values assuming an average log haul of $100 \mathrm{~km}$ and include an allowance for reforestation of $\$ 1.60 / \mathrm{m}^{3}$ of timber harvested. The cost levels chosen include a depreciation allowance for woodlands and mill equipment and machinery.

\section{Conversion Returns}

Revenue per cubic metre of harvest volume less total cost per cubic metre of harvest volume is a residual net revenue or economic rent that accrues to the standing timber at harvest. It is the conversion return, that is, the lumber and chip value after all wood harvest (including reforestation) and milling costs are deducted.

Average conversion returns will vary according to average lumber and chip prices, average harvest and milling

3The inclusion of wood chip production in the analysis is made with the recognition that most Alberta mills at present do not have chippers. However, most of the largest mills (which produce most of the lumber output) do have them (A. MacDonald 1983)

4This CRF is based on data presented by Bigsby (1983). 


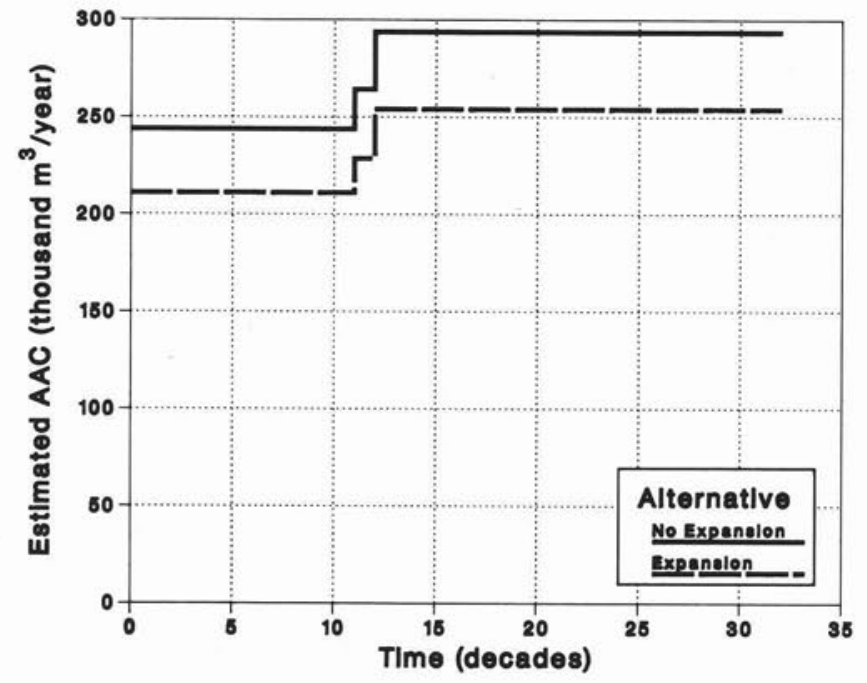

Figure 4. Estimated annual allowable cut ( $\mathrm{m}^{3} /$ year) for FMU P5 under the no agricultural expansion and agricultural expansion alternatives.

costs, and average hauling costs. Table 1 indicates the conversion return for each of our revenue and cost levels. Note that not all of the conversion return estimates are positive. For example, a low revenue of $\$ 45.10 / \mathrm{m}^{3}$ and a high cost of $\$ 53.50 / \mathrm{m}^{3}$ gives a conversion return of $-\$ 8.40 / \mathrm{m}^{3}$.

\section{Opportunity Cost Estimates}

Determination of net present values (NPV) requires the selection of a real discousnt rate, that is, a rate with the inflation component omitted. Debate continues on the relative merits of using a social opportunity cost rate (based on very low risk interest earning opportunities in the private sector) or a lower social time preference rate (based on society's collective desire to recognize benefits to future generations). Neither is readily measurable..$^{5}$ Consequently the choice of a discount rate is somewhat arbitrary. In this study, more than one rate is used. Furthermore, since public forest land use is at

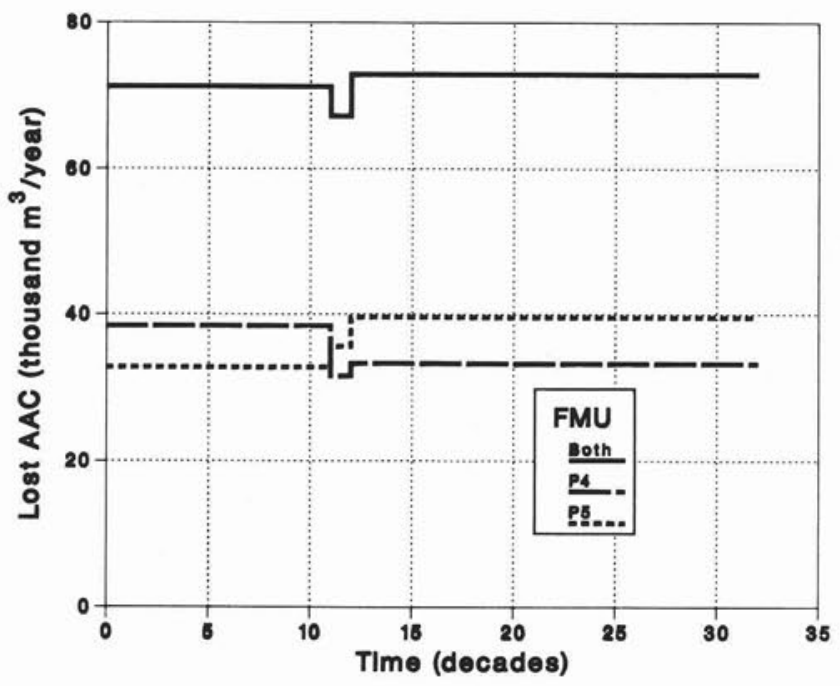

Figure 5. Estimated loss in $\mathrm{ACC}$ ( $\mathrm{m}^{3}$ /year) resulting from agricultural expansion.
Table 1. Estimated conversion return per cubic metre of harvest volume by revenue and cost levels.

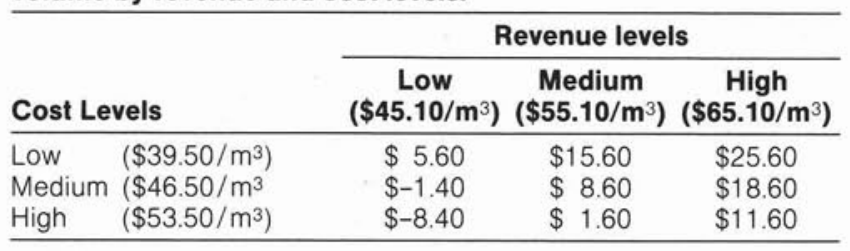

stake, low discount rates, commensurate with the notion of social time preference, are selected.

Table 2 illustrates the opportunity cost calculations using a conversion return of $\$ 8.60 / \mathrm{m}^{3}$ and a $5 \%$ real discount rate. In this particular case, the opportunity cost of agricultural expansion is $\$ 12247500$. To justify an immediate land use change from forestry to agriculture using an economic efficiency criterion, the net present value for agriculture of the land in question must be at least $\$ 12247500$. By dividing this value by the area of productive coniferous timber land displaced (31532 ha) we can determine the value of the displaced land for timber production. This equates to an average value of $\$ 388 / \mathrm{ha}$.

The results to this point have excluded consideration of potential harvest volume to be removed from the agricultural expansion area as salvage. If clearing for agriculture simply involves piling and burning, then the opportunity cost values remain unchanged. However, there is the potential to remove $233850 \mathrm{~m}^{3}$ of merchantable coniferous timber with a value of $\$ 2385000^{6}$ from the agricultural expansion area within FMUs P4 and P5. Assuming that all this potential salvage volume is harvested and sold immediately, the opportunity cost is reduced to $\$ 9862200$ or $\$ 313 /$ ha of productive coniferous land.

Table 2. Illustration of opportunity cost determination.

\begin{tabular}{|c|c|c|c|c|c|}
\hline Years & $\begin{array}{l}\text { Annual } \\
\text { harvest } \\
\text { volume } \\
\text { Loss }\left(\mathbf{m}^{3}\right)\end{array}$ & $\begin{array}{l}\text { Conversion } \\
\text { return } \\
\left(\$ / \mathrm{m}^{3}\right)\end{array}$ & $\begin{array}{c}\text { Annual } \\
\text { rent } \\
\text { loss } \\
(\$)^{\mathrm{a}}\end{array}$ & $\begin{array}{c}\text { Present } \\
\text { value } \\
\text { factor } \\
(5 \%)^{b}\end{array}$ & 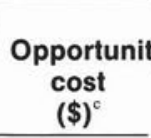 \\
\hline $1-10$ & 71200 & 8.60 & 612400 & 7.72 & 4728800 \\
\hline $11-20$ & 71200 & 8.60 & 612400 & 4.74 & 2903100 \\
\hline $21-30$ & 71200 & 8.60 & 612400 & 2.91 & 1782200 \\
\hline $31-40$ & 71200 & 8.60 & 612400 & 1.79 & 1094100 \\
\hline $41-50$ & 71200 & 8.60 & 612400 & 1.10 & 671710 \\
\hline $51-60$ & 71200 & 8.60 & 612400 & 0.67 & 412370 \\
\hline $61-70$ & 71200 & 8.60 & 612400 & 0.41 & 253160 \\
\hline $71-80$ & 71200 & 8.60 & 612400 & 0.25 & 155420 \\
\hline $81-90$ & 71200 & 8.60 & 612400 & 0.16 & 95414 \\
\hline $91-100$ & 71200 & 8.60 & 612400 & 0.10 & 58576 \\
\hline $101-110$ & 71200 & 8.60 & 612400 & 0.06 & 35960 \\
\hline $111-120$ & 67200 & 8.60 & 577600 & 0.04 & 20823 \\
\hline $121-320$ & 72900 & 8.60 & 626700 & 0.06 & 35937 \\
\hline $321-\infty$ & 72900 & 8.60 & 626700 & 0.00 & 2 \\
\hline
\end{tabular}

Total

12247500

"Column $2 \times$ column 3.

"The present value of one dollar received in each year of the period. 'Column $4 \times$ column 5 .

${ }^{5}$ For a discussion of this issue, see Harou (1985).

6 This value was calculated by multiplying the sum of the conversion return $\left(\$ 8.60 / \mathrm{m}^{3}\right)$ and reforestation costs $\left(\$ 1.60 / \mathrm{m}^{3}\right)$ by the salvage volume. Because the agricultural expansion area will not be reforested, reforestation is not a cost of the salvage harvest. Therefore the $\$ 1.60 / \mathrm{m}^{3}$ reforestation cost must be added to the conversion return. 
Table 3. Opportunity cost sensitivity to different discount rates.

\begin{tabular}{ccc}
\hline \multirow{2}{*}{ Discount rate } & \multicolumn{2}{c}{ Opportunity Cost $\mathbf{( 1 9 8 4 \$ ) ^ { \mathrm { a } }}$} \\
\cline { 2 - 3 } & Without salvage & With salvage $^{\mathrm{b}}$ \\
\hline $5 \%$ & 12247500 & 9862200 \\
$4 \%$ & 15309500 & 12924200 \\
$3 \%$ & 20415800 & 18030500 \\
$2 \%$ & 30652400 & 28267100 \\
$1 \%$ & 61568700 & 59183400
\end{tabular}

Assuming a conversion return of $\$ 8.60 / \mathrm{m}^{3}$

Includes a salvage harvest volume of $233850 \mathrm{~m}^{3}$ taken at the beginning of the agricultural expansion period. Using the conversion return of $\$ 10.20 / \mathrm{m}^{3}\left(\$ 8.60+\$ 1.60 / \mathrm{m}^{3}\right)$ this salvage volume has a value of $\$ 2385300$.

Table 3 demonstrates the extreme sensitivity of the opportunity cost model to discount rate levels. Opportunity cost estimates double when the discount rate is reduced from $5 \%$ to $3 \%$; the opportunity cost estimates using a $1 \%$ discount rate are 6 times those using a $5 \%$ discount rate.

Table 4 presents opportunity cost estimates for different conversion returns and discount rates. The estimates are detrmined assuming both salvage and no salvage, and are expressed in terms of total cost and cost per hectare of displaced productive coniferous land. The opportunity cost estimates range from $-\$ 8900900$ to $\$ 44504300$ (-\$282 to $\$ 1411 /$ ha of productive land). An opportunity cost of $\$ 10$ million to $\$ 20$ million ( $\$ 317$ to $\$ 634 /$ ha of productive land) is not unreasonable. To justify agricultural expansion on an economic efficiency basis, the value of the displaced land for agricultural purposes must exceed these values.

\section{Concluding Comments}

We have presented a model that can be used for determining the opportunity cost of displacing forested land from timber production under sustained timber yield policies. In these circumstances, the opportunity cost of displacement is based on the contribution of the displaced land and the timber on it to the sustained yield annual allowable cut. The value of the non-timber resources produced in a forest are not considered in this model and could increase the values presented in this paper.

We have chosen to ignore the effect of alternative timber flow policies which will alter the rent earning capacity of timber land. In such a case, the opportunity cost of displacing timber land may be considerably changed. The main intent here was to demonstrate an approach that allows economic considerations to be included with other considerations regarding land use trade-offs.

No attempt was made in this paper to determine whether agriculture or timber production is the more efficient use of the land in question. We have, however, demonstrated a method that can be used to determine an important cost of a land use change from timber to agricultural production. This opportunity cost should be taken into account in studies of the costs and benefits of proposed land use changes.
Table 4. Opportunity cost estimates for alternative conversion returns and discount rates.

\begin{tabular}{|c|c|c|c|c|}
\hline \multirow{3}{*}{$\begin{array}{l}\text { Conversion } \\
\text { return } \\
\left(\$ / \mathbf{m}^{3}\right)\end{array}$} & \multicolumn{4}{|c|}{ Opportunity cost at $5 \%$ discount. } \\
\hline & \multicolumn{2}{|c|}{ Without salvage } & \multicolumn{2}{|c|}{ With salvage } \\
\hline & Total & per ha $^{a}$ & Total & per ha \\
\hline $\begin{array}{r}-5.00 \\
0.00 \\
5.00 \\
10.00 \\
15.00 \\
20.00 \\
25.00 \\
\end{array}$ & $\begin{array}{r}-7120700 \\
0 \\
7120700 \\
14241300 \\
21362000 \\
28482700 \\
35603300 \\
\end{array}$ & $\begin{array}{r}226 \\
0 \\
226 \\
452 \\
677 \\
903 \\
1129 \\
\end{array}$ & $\begin{array}{r}-6325600 \\
-\quad 374200 \\
5577300 \\
11528700 \\
17480100 \\
23431500 \\
29382900 \\
\end{array}$ & $\begin{array}{r}201 \\
-\quad 12 \\
177 \\
366 \\
554 \\
743 \\
932 \\
\end{array}$ \\
\hline \multicolumn{5}{|c|}{$\begin{array}{l}\text { Opportunity cost at } 4 \% \text { discount. } \\
\text { Without salvage }\end{array}$} \\
\hline$\left(\$ / m^{3}\right)$ & Total & per ha & Total & per ha \\
\hline $\begin{array}{r}-5.00 \\
0.00 \\
5.00 \\
10.00 \\
15.00 \\
20.00 \\
25.00 \\
\end{array}$ & $\begin{array}{r}-8900900 \\
0 \\
8900900 \\
17801700 \\
26702600 \\
35603500 \\
44504300 \\
\end{array}$ & $\begin{array}{r}282 \\
0 \\
282 \\
565 \\
847 \\
1129 \\
1411\end{array}$ & $\begin{array}{r}-8105800 \\
-\quad 374200 \\
7357500 \\
15089100 \\
22820700 \\
30552300 \\
38283900\end{array}$ & $\begin{array}{r}-\quad 257 \\
-\quad 12 \\
233 \\
479 \\
724 \\
969 \\
1214\end{array}$ \\
\hline
\end{tabular}

"Colum 2 divided by the area of productive coniferous forest land to be displaced by agricultural expansion ( $31532 \mathrm{ha}$ ).

\section{Acknowledgments}

The results of this study rely heavily on the Alberta Forest Service's Phase III inventory. The efforts of Mr. Joe Soos in providing these data and in other regards related to this project are sincerely appreciated. The assistance of Ed Gillespie, Mark Anielski, Tim Williamson, and Neil Stevens is gratefully acknowleged. Funding for this study was provided by the Alberta Forest Development Research Trust. Without this support, the study would not have been feasible.

Thanks are also due to Con Dermott and his staff at the Timber Management Branch of the Alberta Forest Service for their review of an earlier draft of this paper. The comments of Diana Boylen and Al Teskey of the Canadian Forestry Service helped us to clear up some confusing passages in the previous version of the paper.

\section{References}

Bigsby, Hugh. 1983. Land values for forestry in northern Alberta. Alberta Energy and Natural Resources. Edmonton.

Environment Council of Alberta. 1985. Maintaining and expanding the agricultural land base in Alberta: Technical report and recommendations. ECA85-17/RR2. Environment Council of Alberta. Edmonton.

Harou, P.A. 1985. On a social discount rate for forestry. Can. J. For Res. 15: 927-934.

MacDonald, A.P. 1983. The utilization of wood chips in Alberta Unpublished M.Sc. thesis, Dept. Rural Economy, Univ. Alberta.

MacDonald, K. 1983. Potential for agricultural expansion relative to forestry in northern Alberta. Technical Report 83-06-01. Alberta Agriculture. Edmonton.

Navon, D.I. 1971. Timber RAM: A long-range planning method for commercial timber lands and multiple use management. USDA For. Serv. Pacific Southwest Forest and Range Experiment Station. Res. Pap. PSW-70. 